\title{
'N ONDERSOEK NA PARAMETERS VAN PROGNOSTIESE BELANG BY DIE HOOFBESEERDE PASIËNT
}

'N SAMEVATTING VAN 'N VERHANDELING GOEDGEKEUR VIR DIE GRAAD M.CUR. (Int. Alg. Verp.), UNIVERSITEIT VAN PRETORIA, 1981.

\author{
MARGOT HUGO \\ B.Verpl.(US), M.Cur (UP)
}

\section{SUMMARY}

The increase in accidents and accompanying increase in severe head injuries, have led to research into various aspects of parameters of prognostic value in patients suffering from head injuries.

The possible prognostic value of the observations undertaken by nurses was researched by the author. Some of the findings regarding temperature, pulse rate, blood pressure, ventilation, pupillary response and the type of injury are discussed in this article

The importance of accurate observations by nurses is stressed.

${ }^{n} \mathbf{O}$ NDERSOEK is geloods na sommige parameters van prognostiese belang by hoofbeseerde pasiënte ten einde verpleegkundiges positief te motiveer ten opsigte van die hantering van hierdie pasiënte.

Hoofbeserings is ongelukkig die grootste oorsaak van siekte van pasiënte wat neurochirurgiese eenhede besoek en neem ook toe soos wat die wêreld tegnologies ontwikkel. Volgens die statistieke van die Nasionale Verkeersveiligheidsraad was die aantal sterfgevalle in SuidAfrika gedurende 1977 so hoog as 6420 , ernstuge beserings 19879 , en geringe beserings as gevolg van motorvoertuigongelukke so veel as 49882 (16, p.41). Volgens die Departement van Statistiek (1977 verslae) was die aantal noodlottige beserings as gevolg van motorvoertuigongelukke 6532 waarvan 1051 hoofbeserings was $(17,18)$.

Die mortaliteitsyfer vir ernstig hoofbeseerde pasiënte kon sedertdien aansienlik verminder word danksy gespesialiseerde diens en kennis ten opsigte van die patologie en meganisme verbonde aan hoofbese- rings. Ongelukkig is dit so dat sommige pasiënte wat voorheen die beserings nie sou oorleef nie, nou óf 'n vegetatiewe bestaan voer óf erg gestremd gelaat is.

Gedurende die tydperk 28.7.78 tot 26. 10.79 is 166 pasiënte met ernstige hoofbeserings deur die navorser in 'n neurochirurgiese eenheid opgevolg. Met inagneming van die tipes hoof- beserings (sien Tabel 1) is gevind dat hierdie 166 pasiënte inderwaarheid 204 hoofbeserings verteenwoordig het. Die mortaliteitsyfer het $22,29 \%$ (37 uit 166 pasiënte) beloop.

Die voorkoms- en mortaliteitsyfers van die verskillende tipes beserings wat nagevors is word in Tabel 1 weergegee.

\begin{tabular}{|lccc|}
\hline \multicolumn{3}{c|}{ TABEL 1 } & \\
\multicolumn{3}{|c|}{ VOORKOMS- EN MORTALITEITSYFERS VAN } \\
DIE VERSKILLENDE TIPES BESERINGS WAT NAGEVORS IS \\
Beserings & Aantal & $\%$ & Mortaliteitsyfer \\
& & & (in \%) \\
Skedelbasisfrakture & & & 13,43 \\
Konkussie & 67 & 32,84 & 10 \\
Skedelfrakture & 40 & 19,6 & 16,21 \\
Breinstambeserings & 37 & 18,13 & 27,78 \\
Subdurale bloedings & 18 & 8,82 & 75 \\
Missielbeserings & 12 & 5,88 & 60 \\
Intraserebrale bloedings & 10 & 4,9 & 62,5 \\
Diffuse breinskade & 8 & 3,92 & 100 \\
Ekstradurale bloedings & 5 & 2,45 & 100 \\
Ventrikelbloedings & 3 & 1,47 & 50 \\
Breinkontusië & 2 & 0,98 & \\
\hline
\end{tabular}


Parameters wat in die navorsing gebruik was, is:

temperatuur

polsspoed;

bloeddruk;

ventilasie;

pupilreaksie;

tipe besering.

Enkele aspekte met betrekking tot hierdie parameters sal uitgelig word, asook die belang hiervan vir die versorging van die hoofbeseerde pasiënt.

\section{TEMPERATUUR}

Temperatuurregulering is in die sentrale senuweestelsel geleë. Indien die pasiënt dus nie die vermoë besit om normale temperatuur effektief te reguleer en te handhaaf nie, is die besering gewoonlik noodlottig. Waar hiperpireksie teenwoordig is, mag skade aan die brein aangerig word, aangesien dit metabolisme verhoog.

As die weefseltemperatuur met 10 grade Celsius verlaag, neem die metaboliese spoed met ' $n$ faktor van 2,5 af. 'n Verhoging van temperatuur bo normaal inaktiveer die ensieme en ander weefselproteïne en die weefsel word dan vinniger vernietig as wat dit kan herstel.

Liggaamstemperatuur word deur twee verwante meganismes gestabiliseer - wat verwant is omdat hulle 'n gemeenskaplike basis het.

- Die hoogste breinsentra stel die eerste meganisme in werking en word ook soms die ged ragsbeheer van temperatuur genoem. Die meganisme kan buite werking gestel word deur die mens onder diep narkose te plaas.

- Die tweede beheermeganisme is meer suiwer refleksief van aard en staan onder beheer van die laer breinsentra $(8 ;$ p.68.5).

Temperatuurwaarneming in die liggaam is die funksie van temperatuur-gevoelige senuweeselle wat in die vel, diep viscera, rugmurg. medulla. pre-optiese gebied van die breinstam, hipotalamus, mesenkefaliese retikulêre formasie en die motorkorteks geleë is $(8 ; \mathrm{p} .68 .5)$.

Die pre-optiese anterior hipotalamus kan temperatuurskommelinge van so $\mathrm{min}$ as 0,3 grade Celsius waarneem. Waar die brein egter ' $n$ tyd lank aan 'n verhoogde temperatuur (41,5 grade Celsius) blootgestel word, kan permanente breinskade veroorsaak word. Indien die liggaam egter 'n tyd lank onder 26 grade
Celsius afkoel, mag breinskade en ventrikulêre fibrillasie voorkom as gevolg van anoksemie.

Die serebrale sirkulasie neem af teen 'n spoed van $6,7 \%$ vir elke 1 graad Celsius wat die liggaamstemperatuur daal; serebrale metabolisme neem eweneens af en by 25 grade Celsius is dit slegs $33 \%$ van die normale $(8 ;$ p. 70.4).

Die gevare verbonde aan verhoogde temperatuur is:

- potensiële hipovolemie - as gevolg van waterverlies;

suurstofverbruik neem toe en ventilasie moet dus ook toeneem om genoeg suurstof aan die weefsels te voorsien en koolstofdioksied te verwyder; - dehidrasie;

- liggaamstemperatuur styg verder na gelang dehidrasie toeneem;
72 uur reeds begin stabiliseer het

'n Vergelyking is getref tussen die pasiënte wat die besering oorleef het en die pasiënte wat oorlede is, en word in Tabel 2 weergegee.

Hieruit blyk dit dat daar'n tendens van 'n hoër mortaliteitsyfer was in die groepe wat temperatuurafwykings getoon het.

\section{POLSSPOED}

Die akkurate tel van die polsslag sowel as die waarneming van die polsvolume is eweneens belangrik.' $n$ Vol bonsende pols mag'n aanduiding van verhoogde intrakraniale druk wees. Polsspoed kan 'n aanduiding van die volgende wees:

Tagikardie: - hipovolumie;

- hipoksemie;

- die ontwikkeling van transtentoriale her-

\section{TABEL 2}

\section{'N VERGELYKING VAN TEMPERATUURWISSELINGE TUSSEN PASIENTTE WAT OORLEEF HET EN DIE WAT OORLEDE IS.}

\begin{tabular}{lcccc} 
& \multicolumn{2}{c}{$\begin{array}{c}c \\
\text { Oorlewendes }\end{array}$} & \multicolumn{2}{c}{ Oorledenes } \\
& Aantal & $\%$ & Aantal & $\%$ \\
Hiperpireksie & 0 & 0 & 3 & 7,9 \\
Hipotermie & 0 & 0 & 11 & 28,9 \\
Wisselend & 3 & 2,3 & 15 & 39,5 \\
Normaal & 125 & 97,7 & 9 & 23,7 \\
Totaal & 128 & 100,00 & 38 & 100,0 \\
\hline
\end{tabular}

- hartspoed neem toe;

- serebrale skade ontstaan $(8$; p. 70.6).

Indien die pasiënt dus hipotalamiese skade het, mag hy die vermoë om temperatuur te reguleer verloor en mag breinskade verder vererger.

'n Skielike styging van liggaamstemperatuur mag 'n vroeë waarskuwing van 'n geleidelike verhoging in intrakraniale druk wees. Noukeurige temperatuurlesings, liefs rektaal geneem, is dus baie belangrik en moet. veral in die kritieke stadium, een- tot twee-uurliks bepaal word.

Normale temperatuurlesings het die hoogste insidensie in die navorsing getoon. Dit het ook geblyk dat die meeste pasiënte, waar sekondêre komplikasies nie ingetree het nie, na niasie;

- hipotermie;

- 'n geskokte pasiënt;

Bradikardie: - verhoogde intrakraniale druk;

- oormatige ventilasie:

- Vagusstimulasie;

- hartblok (8:p.36.3).

Die verpleegkundige moet bewus wees van die feit dat 'n geleidelike polsspoedvertraging 'n ernstige waarskuwingsteken van die ontwikkeling van verhoogde intrakraniale druk is. Ekstrakraniale bloedings mag ook aanleiding gee tot 'n styging in polsspoed $(8 ; p .33 .1)$

Weereens is daar' $n$ vergelyking getref tussen die pasiënte wat die besering oorleef het en die oorledenes ten opsigte van polsspoedveranderinge. Hierdie statistieke word in Tabel 3 weergegee. 
TABEL 3

\section{'N VERGELYKING VAN POLSSPOEDVERANDERINGE TUSSEN PASIËNTE WAT OORLEEF HET EN DIE WAT OORLEDE IS}

\begin{tabular}{lcccr|} 
& \multicolumn{2}{c}{ Oorlewendes } & \multicolumn{2}{c|}{ Oorledenes } \\
& Aantal & $\%$ & Aantal & $\%$ \\
Tagikardie & 1 & 0,8 & 13 & 34,2 \\
Bradikardie & 0 & 0 & 3 & 7,9 \\
Wisselend & 6 & 4,7 & 14 & 36,8 \\
Normaal & 121 & 94,5 & 8 & 21,1 \\
Totaal & 128 & 100,0 & 37 & 100,0 \\
\hline
\end{tabular}

Uit Tabel 3 blyk dit dat die hoogste mortaliteit voorgekom het by die groepe met abnormale polslesings. Die oorlewende pasiënte het abnormale lesings getoon terwyl hulle diep komateus was, maar polsspoed het binne normale perke gewissel sodra herstel begin intree het. Baie pasiënte het egter 'n peikstyging in polsspoed getoon kort voordat dood ingetree het.

\section{BLOEDDRUK}

Bloeddruk is eweneens 'n belangrike lesing wat deur die verpleegkundige geneem word. In kritieke gevalle kan die lesing selfs kwartuurliks of meer dikwels geneem word. 'n Skielik stygende bloeddruk mag dui op'n verhoging van intrakraniale druk. Die sentra vir bloeddrukregulering is ook in die pons, midbrein, hipotalamus en serebrale skors geleë.

Bloeding in of skade aan die pons gee aanleiding tot styging in die arteriële bloeddruk. Skade aan die midbrein daarenteen laat die bloeddruk met sowat $30 \mathrm{~mm} \mathrm{Hg}$ daal. Aangesien die hipotalamus die hoofsentrum van die outonome senuweestelsel is, is dit die belangrikste wat beheer van die hartfunksie en bloedvaattonus (bloeddruk) betref. Indien die hipotalamus bilateraal vernietig word, vind die kardiovaskulêre veranderinge wat normaalweg met fisieke aktiwiteit geassosieer word, nie plaas nie.

As die serebrospinaalvogdruk tot bokant die sistemiese bloeddruk styg, staak serebrale sirkulasie omdat die hoë intrakraniale druk die arterieë toedruk. In so'n geval, asook met 'n skerp styging in intrakraniale druk na hoofbesering en breinbloe- ding, tree die Cushing-refleks in werking (8;p.36.4-36.5).

Bloeddruk styg ook waar die $\mathrm{pO}_{2}$ akuut daal om sodoende hipoksie teen te werk.

Breinsirkulasie word gehandhaaf en bepaal deur:

- arteriële bloeddruk ekstrakraniaal by die basis van die skedel, en

- die weerstand in die vate intrakraniaal (8;p.39.1-39.2).

Serebrale isgemie veroorsaak hipertensie, omdat dit die aktiwiteit van die kardiovaskulêre beheersentra sodanig wysig dat die aktiwiteit van die hart en perifere weerstand toeneem. Die bloekdruk herstel wanneer die letsel wat tot isgemie aanleiding gee, verwyder word (8;p.40.2)

Bloeddruk moet dus gehandhaaf word om serebrale perfusiedruk te handhaaf. Die verpleegkundige speel dus hier 'n belangrike rol in akkurate waarneming en vroegtydige optrede.

'n Vergelyking is getref tussen die pasiënte wat die besering oorleef het en die oorledenes ten opsigte van bloeddruklesings. Die hoogste mortaliteitsyfer, naamlik $47,4 \%$, is gevind by die groep pasiënte wie se bloeddruk buite normale perke gewissel het, met hipertensie die tweede hoogste, $28,9 \%$ en volgende hipotensie met 'n insidensie van $21,1 \%$.

Twee van die agt pasiënte wat skommelinge in bloeddruk getoon het en die besering oorleef het, het hierdie tendens slegs in die akute stadiums na besering getoon. In hierdie gevalle het bloeddruk na normale perke teruggekeer tydens die herstelfase.
Vier van die pasiënte wat oorleef het, maar hipertensief was, het reeds hipertensie gehad voor die besering. Drie van die oorlewende pasiënte was slegs hipertensief tydens die akute fase maar bloeddruk het na normaal herstel nadat edeem en intrakraniale druk herstel het. Die insidensie van hipertensie by die oorlewende pasiënte sou dus so laag as $3,9 \%$ wees indien hierdie pasiënte buite rekening gelaat word.

Sommige pasiënte het egter 'n piekștyging in bloeddruk getoon voordat dood ingetree het en daarna 'n akute daling. Hierdie tendens sal later bespreek word.

\section{VENTILASIE}

Voldoende ventilasie is baie belangrik by die hoofbeseerde pasiënt. Enige mate van hipoksie, hoe gering ook al, mag aanleiding gee tot verdere breinskade en edeem as gevolg van verhoogde breinperfusie (8;p.36.5,39.4).

Serebrale edeem word deesdae ook met behulp van gekontroleerde hiperventilasie behandel. Die pasiënt word dus geïntubeer voordat hy in 'n toestand van asemnood verkeer.

Pasiënte wat konvulsies kry of deserebrate en dekortikate rigiditeit het, kan nie effektief spontaan ventileer nie, omdat die spiere van die toraks ook in spasma gaan en anoksie, al is dit van korte duur, die bestaande breinskade vererger.

Ventilasiebeheersentra is weereens in die brein en veral dan in die breinstam geleë. (8;p.44.1).

Die $\mathrm{pH}$ van die serebrospinaalvog berus uitsluitlik op die bloedbikarbonaatkonsentrasie. Die dubbele chemiese beheer van serebrale bloedvloei deur die arteriële $\mathrm{pCH}_{2}$ en die serebrospinaalvogbikarbonaat konsentrasie verklaar die vasoparalise wat met laktasidose in die breinweefsel plaasvind.

Om breinasidose teë te werk is dit dus belangrik dat daar:

doeltreffende oksigenase van arteriële bloed, en

- verlaging van arteriële $\mathrm{pCO}_{2}$ sal wer $s$.

Dit word bereik deur intubasie en ‘ckontroleerde hiperventilasie (8;p.39.2-9.3).

Ong:kontroleerde hiperventilasie is egter net so skadelik soos hipo- 
ventilasie, aangesien alle $\mathrm{CO}_{2}$ uitgewas word en die respiratoriese sentra dan nie geprikkel word nie. Oormatige vasospasma kom ook voor en mag tot breinisgemie aanleiding gee (8;p.36.5,39.2).

Meganiese ventilasie word egter net gedurende die akute fase na besering gebruik aangesien die komplikasies verbonde aan meganiese ventilasie ook die siekteproses kan kompliseer. Komplikasies wat mag voorkom is die volgende:

- atelektase;

- infeksie;

- pneumotoraks;

- subkutane emfiseem;

- positiewe waterbalans;

- gastro-intestinale komplikasies;

- trageale skade;

pulmonale suurstoftoksisiteit;

endobrongiale intubasie;

- lugwegobstruksie;

- ontkoppeling van ventilator; onvermoë om pasiënt te speen van ventilator, veral ouer pasiënte met obstruktiewe lugwegsiekte.

(2;p.113-116).

Dit is dus belangrik dat pasiënte nie onnodig meganies geventileer word nie en dat groot sorg gedra word om aseptiese tegniek so ver as moontlik te handhaaf.

Van die 166 pasiënte is 68 meganies geventileer gedurende die eerste 24 uur $(40,96 \%), 64$ gedurende die eerste 48 uur $(38,55 \%)$, na 72 uur is 48 pasiënte geventileer $(30.57 \%)$ en $24.67 \%$ (37) is langer as 72 uur meganies geventileer.

\section{PUPILREAKSIES}

Die verpleegkundige moet bewus wees van die feit dat die verandering van pupilgrootte en -reaksies van kardinale belang is in die diagnosering van 'n ontwikkelende intrakraniale letsel.

Pupilgrootte kan ' $n$ aanduiding wees van die volgende:

'n klein pupil dui op:

- 'n pasiënt aan wie opiaat toegedien is (1:p.784);

ponsbesering en primêre pontiene bloeding (9;p.781);

- bloeding in talamus (12;p.846); serebellêre bloeding (12;p.846);

- metaboliese steurnisse byvoorbeeld uremie (9;p. 781).

'n wyd gedilateerde pupil mag dui op:

verhoogde intrakraniale druk (11;p.499); 'n geskokte pasiënt (8;p40.8);

- midbreinbesering (3;p.74);

- besering aan nervus okulomolorius (N.III) (11;p.491);

- atropien toegedien (11;p.76);

- hipoksie (8;p.40.8)

pupille wat nie ewe groot is nie, kom voor waar:

- Nervus okulomororius eensydig beskadig is (11;p.491); bloeding en 'n hematoom in een hemisfeer teenwoordig is (11; p.491).

Pupille behoort te vernou as daar lig in die oè geskyn word. Pupilarefleksie is 'n swak prognostiese teken, veral as ander oorsake vir gedilateerde pupille uitgeskakel is (11;p.498).

Skade aan nervus okulomotorius sal die ooglid laat hang (ptose), die pupil dilateer en die oog uitwaarts laat draai. Skade aan ander kraniaalsenuwees mag ook voorkom, maar word nie hier bespreek nie, omdat dit nie betrekking het op die pupilgrootte en -reaksie nie (1 l;p.491).

Indien die afferente vesels met albei Edinger-Westphalkerne verbind is, sal beide pupille op lig reageer selfs al word die lig net in een pupil geskyn. Met 'n breinstamletsel, met ander woorde waar daar onderbreking van die efferente been van die ligrefleksboog in die breinstam is, kan bogenoemde refleks nie uitgelok word nie. Beskadiging van die kern van Edinger-Westphal, of beskadiging van nervus okulomororius gee 'n gedilateerde nie-reagerende pupil (8; p. 14.17).

Die verpleegkundige moet dus let op enige verandering in pupilgrootte en hoe flink die pupille op lig reageer. Intrakraniale bloeding, edeem en swelling lei tot verhoogde intrakraniale druk met drukking op die breinstam. Nervus okulomotorius word gevolglik vasgedruk en die pupil dilateer aan die kant van die unkusherniasie, en dus aan die kant van die bloeding.

Uit die navorsing het geblyk dat die pasiënte met pupilarefleksie, of reeds breindood gehad het of serebrale edeem en verhoogde intrakraniale druk het. Die hoogste mortaliteitsyfer is gevind by die pasiënte wie se pupille nie ewe groot was nie en nie verbeter het nadat maatreëls getref is om verhoogde intrakraniale druk en drukking op nervus okulomotorius te verlig nie. By die pasiënte wat oor- lede is, maar normale pupilgrootte en -reaksie getoon het, het pupilreaksieveranderinge ingetree voordat hulle oorlede is.

\section{TIPES BESERINGS \\ Skedelbasisfrakture}

Van die verskillende tipes beserings was $32,84 \%$ skedelbasisfrakture. Die strukture wat betrokke mag wees by skedelbasisfrakture is die volgende:

- die agtste kraniaalsenuwee nervus stato-akoestikus;

membraneuse en benige labirintiene strukture van die binne-oor; - die groot veneuse durale sinusse insluitend die sigmoïedsinus en die superior en interior petrosale sinusse;

- arterie karotis interna;

- buis van Eustagius en middeloor insluitend die mastoïedlugselle;

- eksterne gehoorkanaal en die timpaniese membraan;

- die durale aansluiting van die temporale been in die middel en posterior fossae (12;p.1013).

Die diagnose van 'n skedelbasisfraktuur word hoofsaaklik gemaak met kliniese ondersoek van die pasiënt. Die volgende mag gevind word:

- bloed en serebrospinaalvog in die eksterne gehoorkanaal;

- bloed en/of serebrospinaalvog in die middeloor agter 'n intakte timpaniese membraan;

- frakture deur die eksterne gehoorkanaal;

- kneusing en eggimose oor die mastoïedarea - die sogenaamde "Barrle" teken;

- fasiale paralise of parese;

- vertigo en duiseligheid met nistagmus;

- tinnitus;

- gehooraantasting;

- serebrospinaalvoglek deur die neus - rinoree;

- aantasting van oogsenuwees, veral die derde kraniaalsenuwee (nervus okulomotorius);

- bewysde fraktuur op X-foto (12;p. 1016).

\section{Konkussie}

Die insidensie kan konkussie was 19,6\%. Deur eksperimente van Denny-Brown en Russel kom hulle tot die gevolgtrekking dat konkussie voorkom as gevolg van paralise van verskeie breinstammeganismes. By 
sommige pasiènte was daar afwesigheid van die korneale refleks, staking van asemhaling vir enkele sekondes en/of ' $n$ skerp styging in die bloeddruk wat geleidelik na normaal terugkeer (9;p. 759-763).

Konkussie word gekenmerk deur 'n tydperk van bewusteloosheid wat geleidelik herstel met 'n fase van retrograde en anterograde amnesie.

\section{Skedelfrakture}

Skedelgewelffrakture kan op enige plek van die skedelgewelf voorkom en in die ondersoek was die insidensie van skedelgewelffrakture $18,13 \%$ met 'n mortaliteit van $16,2 \%$.

Skedelfrakture word radiologies bewys. Sommige pasiënte het oop skedelfrakture gehad, met 'n breindefek oor die area en een pasiènt moes om hierdie rede 'n gedeeltelike frontale lobotomie ondergaan. Hierdie pasiënt het 'n volgehoue vegetatiewe bestaan gevoer selfs ses maande na hierdie ondersoek. Gewoonlik het pasiënte met ongekompliseerde frakture van die skedelgewelf egter goed gedoen sonder verdere komplikasies.

\section{Breinstambeserings}

'n Insidensie van $8,82 \%$ breinstambeserings is in die ondersoek gevind, met 'n mortaliteitsyfer van $27,78 \%$. Die pasiënte wat wel oorleef het, voer 'n redelike goeie bestaan, maar het motoriese aantasting met spastisiteit van wisselende intensiteit.

'n Breinstamletsel word gekenmerk deur die volgende:

- deserebrate rigiditeit, gekenmerk deur algemene ekstensorspasma wat voorkom as gevolg van 'n besering of transeksie onder die hoogte van die rooi nukleus;

- dekortikate rigiditeit word gevind waar die besering hoèr as die rooi nukleus geleè is en waar die serebrale korteks ook betrek is;

- akinetiese mutisme mag voorkom;

- algemene slapheid, waar transeksie net onder die vestibulêre nukleus voorkom.

Die kliniese beeld mag dus bestaan uit 'n varièrende graad van verandering in spiertonus en liggaamshouding, verandering in bewussynsvlak, versteurings van vitale funksies, skade aan die kraniaalsenukerne en verandering in spierkrag en koördi- nasie, asook die onvermoë om normale en stabiele bloeddruk, pols en temperatuur te handhaaf (3;p.72).

Beserings aan die midbrein en pons kom hoofsaaklik voor saam met transtentoriale herniasie as gevolg van edeem en/of bloeding supratentoriaal. Indien die dreigende toestand betyds opgemerk en behandel word, mag permanente midbreinskade as gevolg van isgemie vermy word. Diabetes insipidus word ook dikwels in kombinasie met hierdie tipe beserings gevind, aangesien die pituïtêre steeltjie verrekking of drukking mag ondergaan tydens tentoriale herniasie ( $5 ;$ p.45-49).

Met primêre bloeding in die pons mag die pasiënt klein gefikseerde pupille hê ongeag van die intrakraniale druk. By hierdie pasiënte kom daar dan ook 'n skielike temperatuurstyging voor met 'n blywende verhoogde temperatuur (10;p.185).

\section{Subdurale bloedings}

Die insidensie van subdurale bloedings was $5,88 \%$ met 'n mortaliteitsyfer van $75 \%$ (9 uit 12). 'n Diep koma vanaf die tyd van besering, of 'n vinnige agteruitgang in bewussynsvlak, is baie verdag van 'n subdurale bloeding. Dikwels presenteer hierdie pasiënte met 'n kontralaterale hemiparese, hul pupille kan uni- of bilateraal dilateer en daar is verlies van ekstra-okulêre bewegings. Tekens van geleidelike verhoging van intrakraniale druk is ernstige waarskuwingstekens (12:p.963).

\section{Missielbeserings}

$4,9 \%$ Van die beserings was as gevolg van missielbeserings met ' $n$ mortaliteitsyfer van 60\% (6 uit 10). Die aard van beserings by byna elke missielbeseerde was verskillend, aangesien die punt van perforasie en penetrasie verskil het van pasiènt tot pasiënt.

Waar skade aan die ventrikelsisteem of pons voorgekom het, was die besering gewoonlik fataal. Die vier pasiënte wat wel die besering oorleef het, doen redelik goed. Een pasiènt het 'n regter hemiparese en blindheid in die regteroog oorgehou as gevolg van primêre skade. 'n Ander pasiënt het sekondêre meningitis opgedoen as gevolg van serebrospinaalvoglekkasie. Die lek is chirurgies herstel. Die oorblywende twee pasiënte het skynbaar geen neurologiese letsel oorgehou nie.

\section{Intraserebrale bloedings}

Die aard van hierdie beserings het varieer van verskeie klein intraserebrale bloedings tot groot areas van kontusie met bloedings. Agt van die 204 beserings $(3,92 \%)$ het presenteer met intraserebrale bloedings met 'n mortaliteitsyfer van $62,5 \%$. Die diagnose is gemaak deur breinskandering. Die pasiënte was deurgaans diep bewusteloos en dié wat wel herstel het, het geleidelik oor 'n tydperk van 'n paar weke herstel.

\section{Diffuse breinskade}

$2,45 \%$ Van die gevalle het presenteer met diffuse breinskade met ' $n$ mortaliteitsyfer van $100 \%$. Dié tipe besering kom hoofsaaklik voor na vaartvertragende beserings tydens hoè-snelheidsmotorvoertuigongelukke. Die pasiënte mag 'n onbepaalde tyd - selfs maande lank - in 'n diep koma wees en aan sekondêre komplikasies sterf. By nadoodse ondersoek van hierdie pasiënte is breinatrofie, veral in die omgewing van die derde ventrikel en boonste breinstam gevind. Waar die besering fataal van aard is, is die kardiale en respiratoriese sentra aangetas en die pasiënt oorleef nie die aanvanklike a noksiese periode nie (3;p.40).

\section{Ekstradurale bloedings}

Slegs drie pasiënte het presenteer met 'n ekstradurale bloeding $(1,47 \%)$ en almal het volkome herstel nadat die hematoom chirurgies verwyder is.

Ekstradurale bloeding moet vermoed word by enige skedelfraktuur, aangesien die dura mag losskeur van die kranium en sodoende bloedvate skeur. Die bloedings mag gering wees met 'n spontane staking van die bloeding. Chirurgie kan gedoen word nadat die posisie van die fraktuur en bloeding met behulp van Xfoto's en breinskandering bepaal is.

By ernstiger beserings mag die klassieke beeld van die lusiede periode ook voorkom. Soos die bloeding toeneem in volume verhoog die intrakraniale druk met gevolglike agteruitgang van die bewussynsvlak. $\mathrm{Na}$ chirurgiese verwydering van die hematoom herstel die pasiënte gewoonlik goed indien sekondêre skade as gevolg van verhoogde intra- 
kraniale druk nie aangerig is nie. Die posisie van die bloeding mag varieer van anterior, middel, parasagittale tot posterior fossa (3;p.64-69).

\section{Ventrikelbloedings}

Hierdie toestand is gewoonlik met behulp van breinskandering gediagnoseer. Twee pasiënte het met bloeding in die ventrikels presenteer, maar albei is binne $\mathbf{4 8}$ uur na opname oorlede.

Die komplikasie van intraventrikulêre bloedings mag of ventrikulitis of obstruktiewe hidrokefalie wees. Ventrikulêre dilatasie is egter'n swak prognostiese teken (6;p.251,252).

\section{Breinkontusie}

Die mortaliteitsyfer by pasiënte met kontusie van die brein het $50 \%$ beloop. Powiertowski het in 'n studie van 100 pasiënte met breinstambeserings ' $n$ insidensie van $61 \%$ van breinstamkontusie gevind (4;p.331). Seitelberger en Jellinger vind ' $n$ insidensie van $67 \%$ met kortikale kontusie by hul pasiënte wat langer as 10 dae geleef het, hoewel sommige van die letsels mikroskopies klein was. In 'n kontrolegroep pasiënte wat minder as twee dae in 'n koma was, was die insidensie van kontusie so hoog as 91\%. Die gemiddelde voorkoms van kortikale kontusie van beide groepe pasiënte was $85 \%$. Baie van die diagnoses is egter tydens chirurgie of by nadoodse ondersoek gemaak (4;p.241,242)

Met kontusie kan areas van mikroskopiese skade aan neurone en bindingsvesels veroorsaak word en die pasiënt kan maande lank 'n vegetatiewe bestaan voer indien die skade uitgebreid is (6;p.57).

Dit blyk dus dat die prognose beter is hoe meer oppervlakkig die skade is. Sodra die besering in die omgewing van die midbrein voorkom of waar uitgebreide skade voorkom styg die mortaliteitsyfer dramaties soos blyk uit Grafiek I en Tabel 4

Daar moet egter aangetoon word dat observasies by feitlik alle pasiënte wat transtentoriale herniasie gehad het min of meer dieselfde patroon gevolg het, naamlik:

- namate die intrakraniale druk gestyg het, het die bloeddruk gestyg, polsspoed gedaal, temperatuur gestyg en was die pupille nie ewe groot nie en mag of mag nie op lig
TABEL 4

\section{MORTALITEITSYFERS BY VERSKILLENDE TIPES BESERINGS IN DIE ONDERSOEKGROEP}

$\begin{array}{rlc}\text { No. } & \text { Tipe besering } & \text { Mortaliteitsyfers (in \%) } \\ 1 & \text { Ekstradurale bloedings } & 0 \\ 2 & \text { Konkussie } & 10 \\ 3 & \text { Skedelbasisfrakture } & 13,43 \\ 4 & \text { Skedelfrakture } & 16,21 \\ 5 & \text { Breinstambeserings } & 27,78 \\ 6 & \text { Kontusie } & 50 \\ 7 & \text { Missielbeserings } & 60 \\ 8 & \text { Intraserebrale bloedings } & 62,5 \\ 9 & \text { Subdurale bloedings } & 75 \\ 10 & \text { Ventrikelbloedings } & 100 \\ 11 & \text { Diffuse breinskade } & 100 \\ \end{array}$

\section{GRAFIEK 1}

\section{MORTALITEITSYFERS BY VERSKILLENDE TIPES BESERINGS IN DIE ONDERSOEKGROEP}

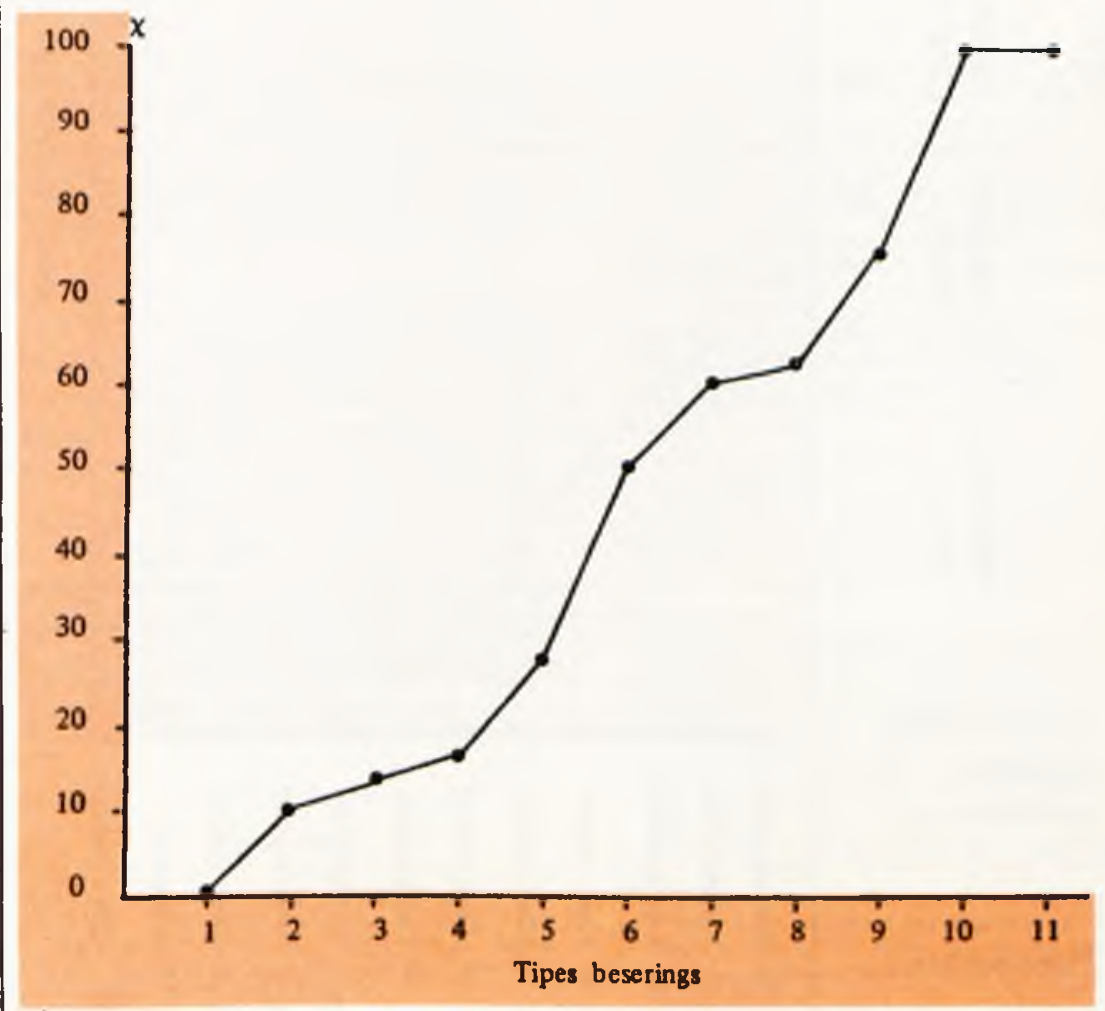




\section{FIGUUR 1}

\section{OBSERVASIEKAART VAN 'N PASIENT SOOS TYDENS TRANSTENTORIALE HERNIASIE}

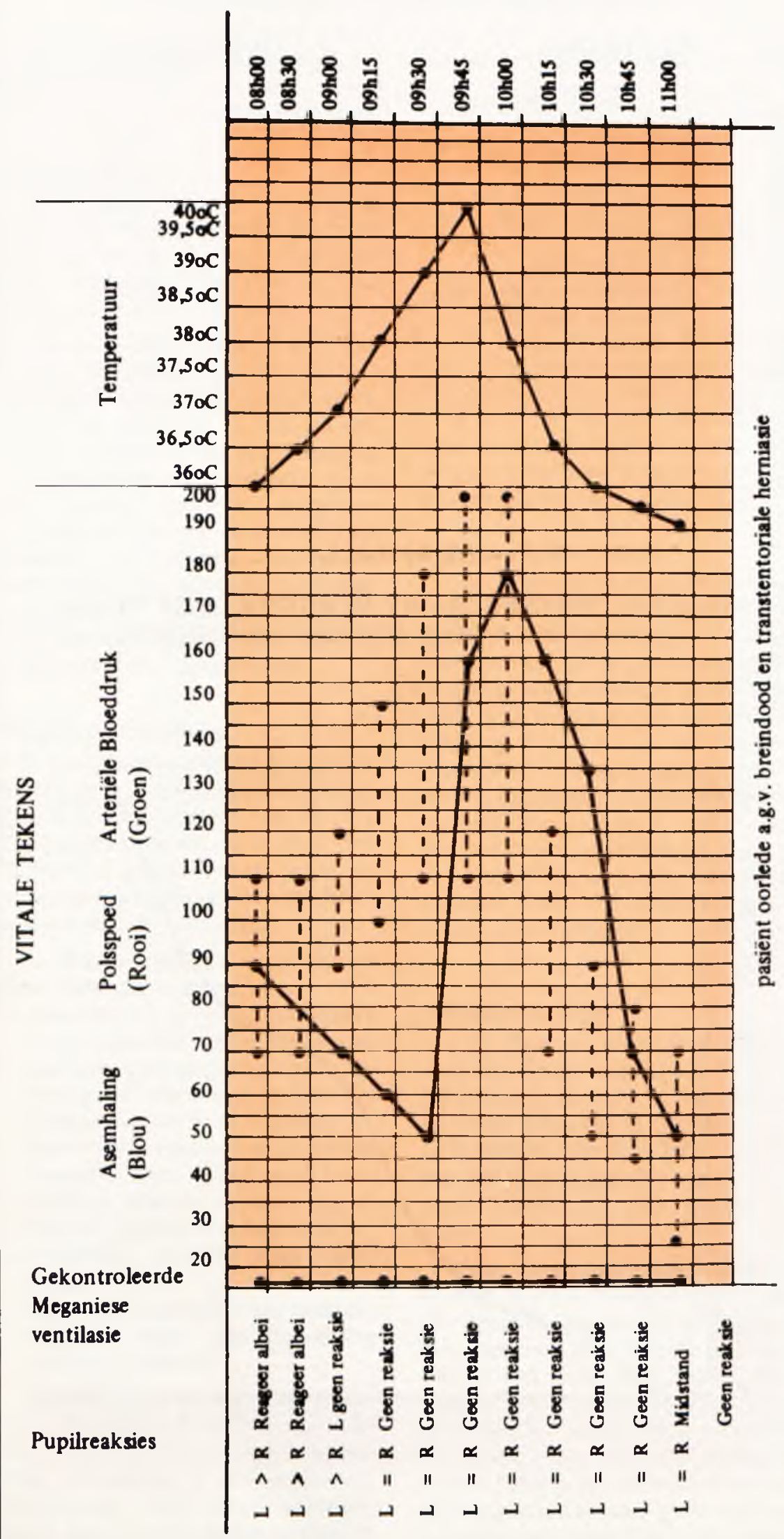

gereageer het nie;

-- net voor of tydens herniasie het die bloeddruk gestyg, tagikardie het voorgekom, die temperatuur het gestyg en die pupille het nie op lig reageer nie;

- sodra breindood as gevolg van verhoogde intrakraniale druk en herniasie ingetree het, het die bloeddruk gedaal, polsspoed gedaal, die temperatuur subnormaal geword en die pupille was gedilateer in midstand met geen reaksie op lig nie.

Spontane asemhalingspogings het ook verdwyn, maar aangesien al die pasiënte wat gesterf het meganies geventileer is, kon ventilasie nie as parameter gebruik word nie.

Op 'n observasiekaart het die beeld gelyk soos geïllustreer in Figuur 1.

\section{SLOT}

Soos blyk uit die statistieke wat hierbo bespreek is, het die hoogste mortaliteit voorgekom by die pasiënte wat nie bloeddruk, pols en temperatuur binne die normale perke kon handhaaf nie. Die toestand van pasiënte wat dus groot skommelinge by dié ondersoeke toon moet in 'n ernstige lig beskou word, sangesien dit 'n aanduiding mag wees dat die vitale sentra aangetas en beskadig is.

Hoewel die ses parameters wat deur die navorser ondersoek is nie die werklike prognose kon bepaal nie, is dit wel van belang in die sin dat afwykings van die normale as ernstige waarskuwingstekens beskou moet word. Vinnige en doeltreffende optrede mag dus lewensreddend wees. Sien Tabel 5 vir tekens van verhoging in intrakraniale druk.

Dit blyk verder dat die meeste pasiënte binne drie dae na die besering reeds begin stabiliseer en dan geleidelik verbeter, mits sekondêre komplikasies nie ontwikkel nie. Hierdie bevinding stem ooreen met bevindings van Jennet, naamlik dat die beraamde prognose nie veel veri nder radat data van dag 4 tot 7 ook jygevueg is nie $(7 ;$ p.45).

Teasdale en Jennet het in 1974 'n komaskaal ontwerp in 'n poging om die mo sntlike gevolge na hoofbesering of ' $n$ glyskaal te bepaal. Bond is 


\section{TABEL 5}

\section{KLINIESE TEKENS VAN VERHOGING IN INTRAKRANIALE DRUK}

\section{Normaal - geen verhoging in druk}

Bewussynsvlak

Motoriese reaksie

Pupilreaksie

Polsspoed

Bloeddruk

Asemhaling

Temperatuur
Wakker en georiënteerd

Gehoorsaam bevele

Ewe groot en reageer flink op lig

Normale speling vir pasiënt

Normaal vir pasiënt

Normaal vir pasiënt

Normaal
Verhoging in druk -
Behandeling belangrik

Stupor, moeilik om wakker te maak, oriëntasie neem af

Doelgerigte beweging of wegtrek van pyn, afname in spierkrag aan een kant

Nie ewe groot - reageer traag, ipsilateraal gedilateer en gefikseerd

Bradikardie - vol en bonsend

Bloeddruk styg - sistoliese druk eerste

Asemhalingsprobleme, mag hiper- of hipoventileer

Verhoog

\section{Dekompenseer - Behandeling is dikwels te laat}

Geen reaksie - kan nie praat of op bevele reageer nie

Nie doelgerig, of deserebrate/ dekortikate houding

Beide pupille gedilateer en arefleksief

Toename tot tagikardie, disritme mag voorkom

Hou aan styg tot kollaps

Onreëlmatige en periodieke asemhaling

Styg vinnig
TABEL 6

\section{DIE GLASGOW KOMASKAAL}

\section{The Glasgow Coma Scale}

\section{Eye opening:}

Spontaneous

To speech

To pain

None

Best verbal response:

Oriented

Confused conversation

Inappropriate speech

Incomprehensible sounds

None

\section{Best motor response:}

Obeys commands

Localizing response

Withdrawal

Abnormal flexion

Abnormal extension

None van mening dat die implementering van die Glasgow' Coma Scale wel 'n betekenisvolle rol speel in die bepaling van die prognose van die ernstig hoofbeseerde pasiënt (14:p.105).

Vir die doel van hierdie artikel word die gespesialiseerde ondersoeke vir die bepaling van prognose nie bespreek nie. 'n Voorbeeld van die komaskaal word in Tabel 6 gegee.

Dit is duidelik dat die waarnemings wat deur die verpleegkundige gedoen word 'n waardevolle rol speel by die uiteindelike prognose van die hoofbeseerde pasiënt.

L.lleratuurlys

Boeke:

Brunner LS: Emerson. C.P. Furguson. I.K Suddarth. D.S. Textherek of Medicat-Surgical Aursing J.B. Lippencout Company. Philadelphia, New York. Toronto. 1964. Second Edition.

Bushnel. S.S. Respirarory Intensisy Cars Nursing L.iule. Brown and Company, Boston. 1973. First Edition Hooper, R. Putterm of Acute Heod Imjurl. Edward Arnold (Publishers) l.td. L.ondon. 1969

Incernotiunal Simpesium on Heod Injuries. Churchill Livingsine Edinhurgh london. 197

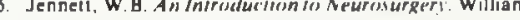
Heinemann Medical Books L.dd. I.ondon. 1970. Second edition.

6. L.ewin. W. The Monugement of Head Iniuries. Bailliére. Tindall \& Cassell London. 1966

Mclaurin, R.L. Head injuries. Second Chicag Simposium on Newal Trauma. Grune \& Stratton. Inc. New York, San Francisco. London. 1976.

8. Meyer. B.J. Die Fisinlogiese Basis ven Geneesilunde H.A.U.M. Kaapstad. Pretoria. 1976

9. Northfield. D.W.C. The Surgery of the Central Vervous Sysem. Blackwell Scientific Publications. Oxford. L.ondon. Edinburgh. Melbourne. 1973

10. Rowbotham. G.F. Acute Injuries of the Heud. E. \& S Livingstone L.td. Edinburgh, London. 1964. Fourth edition

Ylok, M.E: Schreiber, I.. A. Manual of Adranced Nursing. Hayne \& Gibson. Johannesburg. 1976. Second edition.

12. Yourmans. J.R. Neurulugical Surgers. Vol 2. W. B Saunders Company Philadelphia, London. Toronto. 1973.

Tydar rifte:

13 Allen. $X$ Prognosite indicalors in coma. Heart and l.ung. Vol 8. No 6. Nov Dec 1979. p. 1075-108

14. Band M.R Assessment of outcome following severe closed head injury. Scutrish Medical Jusurnal. Vol 23 No 1 Jan 1978 D. 105.106

15. Johnson. Marion R. Emergency Management of Head and Spinal Injuries. Nursing Cliniss of North Americu and Spinal Injuries. Nursing Clini
Vol 8 . No 3. Sept 197.3. p.389.399.

16. Van Tonder, S. Aspekte van Trouma as 'n Gesondheid. probleem. Curarimix, Vol I. No 4. Maarl 1979. p.40-4.

Ander bronne:

17. Statistick Departemenı san. Republiek เan Suid Afrika Verslag nr. 07-03-19. J'erslag our werfgevialle' van Swares in uingessehte landdrowdisurikite 1977. Staatsdrukker. Preioria.

8. Statistiek Departement van. Republiek van SuidAfrika. Verslag nr. 07-03-16. Lerslog oor sterfgevalle: Blunkips, Kleurlinge on Asiers .1977. Sialsdrukker. Preloria.

9. Waarnemings Norme ian die Departement Neurochirurgic. 